\title{
The Study on Relationship Verification of e-wom and Hotel Operation Performance by Data Mining Technique
}

\section{Yu-His Yuan*}

Department of Food and Beverage Management, Yuanpei University of Medical Technology, Hsinchu City, Taiwan

\begin{abstract}
The power of e-word-of-mouth are impact Hotel industry dramatically in the recent years. The Ambassador Hotel Group is a five-star rated business hotel type in Taiwan. Quantitative and qualitative data are retrieved from internet respectively based on data mining technique. Descriptive and regression analysis approach are used for quantitative data, meanwhile, text analysis and words meaning assortment are used for qualitative data. Result demonstrated that higher internet exposure rate will impact hotel's operating performance positively. 'Services' is most important factor toward reviewer's perspective regarding hotel impression. Otherwise, 'Services' is most comment word appeared in the reviews. Some suggestions are mentioned base on research findings.
\end{abstract}

Keywords: E-word-of-mouth; Ambassador hotel; Operating performance; Data mining

\section{Introduction}

Globalization, is a new rise concept in the 21st century. Under the concept of "global village", tourism industry could be the one of typical in form of cultural globalization.

According to the statistics of Tourism Bureau of Taiwan, the number of inbound visitor reached over 7 million in 2012 and increasing continuously over the past decade [1]. Hospitality industry as a part of tourism industry has taken benefit from it. Many researches on hotel operating performance have been done in method of interview. With the science technology developing and the network popularization, data mining, a method which integrates statistic and computer science rises for the features of rapidly analysis and get closer to the extensive subjects. Furthermore, there is one another new concept generated from the network popularization, e-Marketing. An increasing number of consumer sharing their user experience through blog, facebook or network and eventually becomes a network reviews. A majority of "first-time user" determines the quality of goods or services depends on network reviews thus constitutes another new marketing skill, Mouth Marketing. The purpose of this study was to investigate the impact of business hotel operating performance from e-word-of-mouth (e-WOM) through the method of data mining.

\section{Literature Review}

\section{Hotel background}

Ambassador Hotel Group was established on December 1, 1962, to response the call of the government to promote the tourism industry with a project of the premier international tourist hotel constructionAmbassador Hotel Taipei in capital of sixty million New Taiwan Dollars and in 1982 was listed on the Taiwan Stock Exchange [1].

As the leading brand of Taiwan's five-star tourist hotel, the Ambassador has sustained to explore the market of Taiwan to support the tourism industry. The Ambassador emphasized the integrity, teamwork, innovation, and the spirit of contribution to society as their principle of operating to business [2].

The first hotel of Ambassador was opened at Taipei Zhongshan North Road in year of 1964 as the first five-star hotel in Taiwan, with the market positioned of "Classical Hotel of Taiwan". The Ambassador
Hotel Kaohsiung started construction on year of 1978 and which was officially opened in year of 1981, located at side of LoveRiver with the market positioned of "Urban Leisure Hotel". Fifteen years later, the Ambassador Hotel Hsinchu was officially opened on May of 2001 with the market positioned of "Luxury Business Hotel".

Apart from accommodation, the Ambassador also provided variety of cuisine such as Cantonese Cuisine, Szechuan Cuisine, Aqua Lounge, Buffet and Café. Afterwards, a pastry shop Le Bouquet established on 2005, A CUT Steakhouse grand opened on 2007, five star buffet Market Café was opened on December of 2008, Yu Sushi, oriented as new style contemporary Japanese Restaurant was opened on February of 2009, and the latest dining brand 1Bite2Go Café \& Deli, serves the New Yorkstyle American food, including fresh hand-made feature sandwiches, was established on 2012. In addition, the Ambassador also get involved in the business of hairdressing salon, laundry service, swimming pool operating, car park, sauna, GYM room and store renting etc. [2].

\section{Data mining}

"Data mining" introduced by Frawley, Paitetsky-Shapiro and Matheus of the term as early as 1991, which is defined as "...is the nontrivial extraction of implicit, previously unknown, and potentially useful information from data." [3,4] raised a similar definition to the data mining, "Data mining is the application of specific algorithms for extracting patterns from data". In recent years have seen the growing of the technology of data mining research [4] deemed that data mining is an investigation of the valuable data from a database and widely used in the field of data processing [5] deemed that the application of the system of information technology should makes user receive the information according to their requirement instead of others useless

*Corresponding author: Yu-His Yuan, Department of Food and Beverage Management, Yuanpei University of Medical Technology Hsinchu City, Taiwan, Tel: 888635381183; E-mail: yuanyh@mail.ypu.edu.tw

Received October 06, 2014; Accepted January 06, 2015; Published January 16 2015

Citation: Yuan YH (2015) The Study on Relationship Verification of e-wom and Hotel Operation Performance by Data Mining Technique. J Glob Econ 3: 130 doi:10.4172/2375-4389.1000130

Copyright: (c) 2015 Yuan YH. This is an open-access article distributed under the terms of the Creative Commons Attribution License, which permits unrestricted use, distribution, and reproduction in any medium, provided the original author and source are credited. 
Citation: Yuan YH (2015) The Study on Relationship Verification of e-wom and Hotel Operation Performance by Data Mining Technique. J Glob Econ 3: 130. doi:10.4172/2375-4389.1000130

Page 2 of 4

information.

\section{Mouth marketing}

Word of Mouth is a straightforward but informal way of communication in the human society, which could influence consumer behavior in either short or long period [6,7]. Since the internet becomes more popularity, the effect of word of mouth is no longer confined in the way of communication by face to face. Internet has given an opportunity for consumer to share their user experience which these information and reviews could be receive by one another consumer as a first-time user and further influence their purchasing decision, is referred to as e-WOM [8]. Usually, Word of Mouth Marketing emphasized on transaction between market and consumer, in fact, there is concerning about the value of goods or services bring to consumers well. E-WOM marketing believe that consumer will not necessarily to consume from the reason of good reputation in WOM, but a good reputation in WOM will make consumer accelerate in purchasing decision making and more influence their original opinion. To the consumer, company, goods or services with a good reputation in WOM will more easier to make consumers purchasing and coming back for it [9].

\section{Methods}

\section{Data collection}

To verify the authenticity of analysis results for triangulation which including quantitative data and qualitative data. All data used in this study were retrieved from multi-resources and based on data mining technique. First, the data of financial statements (URL: www. ambassadorhotel.com.tw/financial/financial.htm) and the internet search results by term of "Ambassador Hotel" are collected through Google search respectively. Hence, the relationship between operating performance [10] and internet exposure rate are examined. The collected data are divided in quarter from 2008 to 2013 (Table 1).

\begin{tabular}{|c|c|c|c|}
\hline Year & Quarter & $\begin{array}{c}\text { Ambassador Hotel Hsinchu } \\
\text { operation income }\end{array}$ & Internet search result \\
\hline \multirow[t]{4}{*}{2008} & Q1 & $727,840,000$ & 3,250 \\
\hline & Q2 & $691,244,000$ & 4,930 \\
\hline & Q3 & $612,740,000$ & 6,760 \\
\hline & Q4 & $689,937,000$ & 7,760 \\
\hline \multirow[t]{4}{*}{2009} & Q1 & $603,447,000$ & 6,240 \\
\hline & Q2 & $557,326,000$ & 8,630 \\
\hline & Q3 & $586,057,000$ & 8,520 \\
\hline & Q4 & $681,824,000$ & 8,130 \\
\hline \multirow[t]{4}{*}{2010} & Q1 & $691,613,000$ & 6,860 \\
\hline & Q2 & $624,111,000$ & 9,490 \\
\hline & Q3 & $620,217,000$ & 10,800 \\
\hline & Q4 & $708,472,000$ & 11,300 \\
\hline \multirow[t]{4}{*}{2011} & Q1 & $726,825,000$ & 9,390 \\
\hline & Q2 & $671,679,000$ & 13,100 \\
\hline & Q3 & $657,801,000$ & 11,000 \\
\hline & Q4 & $776,374,000$ & 14,300 \\
\hline \multirow[t]{4}{*}{2012} & Q1 & $783,871,000$ & 13,000 \\
\hline & Q2 & $735,542,000$ & 17,800 \\
\hline & Q3 & $722,125,000$ & 19,700 \\
\hline & Q4 & $817,606,000$ & 28,500 \\
\hline \multirow[t]{3}{*}{2013} & Q1 & $824,920,000$ & 25,000 \\
\hline & Q2 & $742,904,000$ & 41,400 \\
\hline & Q3 & $772,937,000$ & 49,300 \\
\hline
\end{tabular}

\begin{tabular}{|c|c|}
\hline Item & Description \\
\hline Resource & Trip Advisor \\
\hline Sample & Ambassador Hotel Hsinchu \\
\hline Number of consumer reviews & 97 \\
\hline Reviews period & September 2006 to November 2013 \\
\hline
\end{tabular}

Table 2: Summary of the qualitative dataset.

\begin{tabular}{|c|c|c|c|}
\hline Item & Taipei & Hsinchu & Kaohsiung \\
\hline Founded & 1964 & 2001 & 1981 \\
\hline Class & 5 stars & 5 stars & 5 stars \\
\hline Rooms & 416 & 257 & 453 \\
\hline Distinguishing feature & $\begin{array}{c}\text { Classical Hotel } \\
\text { of Taiwan }\end{array}$ & $\begin{array}{l}\text { Luxury } \\
\text { Business } \\
\text { Hotel }\end{array}$ & $\begin{array}{c}\text { Urban Leisure } \\
\text { Hotel }\end{array}$ \\
\hline $\begin{array}{l}\text { Average operation income } \\
\text { (based on } 2008_{Q 1} \text { to } 2013_{Q 3} \text { ) }\end{array}$ & \multicolumn{3}{|c|}{ NTD. $696,844,000 /$ Quarter } \\
\hline
\end{tabular}

Second, the e-WOM indicators are retrieved and weighted from TripAdvisor (URL: www.tripadvisor.com.tw), which is the famous website of consumer-generated reviews on hotel and catering in Taiwan [11]. The data are ranged from 2006 to 2013 (Table 2). All data are collected manually by researchers from internet on December 12th to 16 th, 2013.

\section{Analysis}

A multi-analysis approach are used in this research [12]. The descriptive analysis and simple regression are used for quantitative data analysis. Text analysis and words meaning assortment are employed as research approach for qualitative data.

\section{Results}

\section{The characteristic of sample}

As shows in Table 3, the type of Ambassador Hotel [13] is classified as business hotel. Ambassador Hotel Hsinchu is the newest compared with other two Ambassador Hotels in Taiwan. All of the belonged hotels are 5 stars rated by Taiwan Tourist Hotel Association. The largest capacity of hotel rooms is Ambassador Hotel Kaohsiung, but Ambassador Hotel Hsinchuis the smallest one. The features of each hotel are different: Ambassador Hotel Hsinchuis positioned as Luxury Business Hotel [14]. The average operation income of Ambassador Hotels were NTD. 696,844,000 in quarter (Table 3).

\section{A positive relationship to be detected}

As indicated in Table 4, there is a significant relationship between operating performance (dependent variable) and internet exposure rate (independent variable) with an Adjusted $\mathrm{R}^{2}$ of $28.3 \%$. The result supported that the internet exposure rate can predict the Ambassador Hotels operating performance positively [15]. The detailed functions as following.

Unstandardized regression function:

$y=3,566.971 X$ $+64,486,5479.698$

Standardized regression function:

$y=.562 X$ (Table 4) 


\begin{tabular}{|c|c|c|c|c|c|c|c|}
\hline $\mathbf{X}$ & $\mathbf{R}$ & $\mathbf{R}^{\mathbf{2}}$ & $\mathbf{+ R}^{\mathbf{2}}$ & $\mathbf{F}$ & $\mathbf{b}$ & $\boldsymbol{\beta}$ & $\mathbf{t}$ \\
\hline (Constant) & & & & & $644,865,479.698$ & & $30.531^{\star \star *}$ \\
\hline Coefficients & .562 & .316 & .283 & $9.690^{\star *}$ & $3,566.971$ & .562 & $3.113^{* *}$ \\
\hline
\end{tabular}

Note: $X=$ independent variable; $+R^{2}=$ Adjusted $R$ square; $b=$ unstandardized coefficients; $\beta=$ standardized coefficients; ${ }^{* *} p<.01 ;{ }^{* * *} p<.001$.

Table 4: Summary of regression analysis results.

\begin{tabular}{|l|c|c|c|}
\hline Indicators & $\begin{array}{r}\text { Response } \\
\text { frequency }\end{array}$ & Indicators & Mean scores \\
\hline Services & 78 & Sanitary and cleanliness & 4.844 \\
\hline $\begin{array}{l}\text { Sanitary and } \\
\text { cleanliness }\end{array}$ & 77 & $\begin{array}{c}\text { Booking and check-in } \\
\text { services }\end{array}$ & 4.750 \\
\hline Price & 75 & Business services & 4.750 \\
\hline Location & 73 & Services & 4.744 \\
\hline $\begin{array}{l}\text { Environmental } \\
\text { comfortable }\end{array}$ & 73 & Environmental comfortable & 4.644 \\
\hline Sleeping quality & 64 & Sleeping quality & 4.609 \\
\hline $\begin{array}{l}\text { Booking and check-in } \\
\text { services }\end{array}$ & 8 & Price & 4.400 \\
\hline Business services & 8 & Location & 4.301 \\
\hline Total & 456 & Overall & 4.630 \\
\hline
\end{tabular}

Table 5: Frequency and mean scores of e-word-of-mouth indicators.

\section{The rating of e-word-of-mouth indicators}

Total 456 rated responses of 8 factors including "Booking and check-in services", "Price", "Location", "Services", "Business services", "Sanitary and cleanliness", "Environmental comfortable", and "Sleeping quality", in Likert's 5 point scale which retrieved from Trip Advisor website. The analyzed results were show in Table 5.

According to the response frequency, "Services" is the frequently word that responded by reviewers, "Sanitary and cleanliness" and "Price" are the second and third indicators (Table 5) [16]. On the contrary, "Business services" and "Booking and check-in services" are the least indicators in this list. However, the mean scores of Ambassador Hotel Hsinchu rating are provided difference results. The "Sanitary and cleanliness" obtained the highest satisfaction scores, furthermore, "Booking and check-in services" and "Business services" as second satisfied factors rated by reviewers.

\section{The review of e-word-of-mouth recommendations}

The purpose of reviewers to dwell in the Ambassador Hotel Hsinchuis mainly for business trip, only few reviewers for leisure tour. All text recommendations are reviewed and 8 keywords to be noted. The most comment word is "Services". The words "Environment and facilities", "Foods and beverages", and "Location" are also to be promoted by reviewers. Meanwhile, "Price" and "Traffic" are slightly needed to be promoted compared with other words.

\section{Conclusions and Suggestions}

\section{Conclusions}

Ambassador Hotel Hsinchu is set as "Luxury Business Hotel" and located at Hsinchu, the part of northern Taiwan. The researchers found a positive relationship between operating performance and internet exposure rate. It demonstrated that higher internet exposure rate will impact hotel's operating performance positively.

From the reviews of Hotel Rating from Trip Advisor indicating that the "Services" is the most important factor which impact reviewer's satisfaction toward Ambassador Hotel Hsinchu.
On the other hand, empirical findings of e-WOM analysis indicated that reviewers are satisfied Hotel's sanitary and cleanliness, Booking and check-in services, and Business services. An inconsistence results appeared compare with Hotel Rating. Customers are satisfied their services provided by Ambassador Hotel Hsinchu. This point shall be further investigated to discover the actual reason.

\section{Suggestions}

Some empirical suggestions are provided based on research results for hospitality industry as supporting information for decision making. Obviously, necessary specified strategies shall be provided to promote internet exposure rate. This action can enhance operating performance of Ambassador Hotel.

Further, "Services" and "Price" shall be improved immediately to motivate reviewers' impress regarding to the Ambassador Hotel Hsinchu. In addition, the weakness of hotel location shall be improved by enhance transportation services to promote the reviewers' satisfaction. Otherwise, customer's interview shall be conducted to understand the reason of inconsistence between Hotel Rating and e-WOM.

In summary, more positive e-WOM recommendations can facilitate Hotel's operating performance. This finding complied with recent researches $[11,15,17]$. Therefore, Hotel executives shall assign importance to e-WOM and give some supports to reviewers on related websites.

\section{References}

1. MOTC (2013) iTaiwan, Like! International tourist free access wifi. Ministry of Transportation and Communications R.O.C.

2. Ambassador Hotel (2012) Introduction Retrieved on December 17.

3. Frawley WJ, Shapiro GP, Matheus CJ (1992) Knowledge Discovery in Databases: An Overview 13.

4. Bruin AKM, Ibelings BW, Donk EV (2007) Parasitic chytrids: Their effects on phytoplankton communities and food-web dynamics. Hydrobiologia 578 113-129.

5. Nicholson J (2006) Computer-mediated learning: An empirical examination of the influence of technology, task, and individual characteristics. Unpublished Ph.D. Dissertation, Washington State University.

6. Richins ML, Shaffer RT (1988) The role of involvement and opinion leadership in consumer word-of-mouth: an implicit model made explicit. Advances in Consumer Research 15: 32

7. Herr PM, Frank RK, Kim J (1991) Effects of word-of-mouth and product attribute information on persuasion: an accessibility-diagnostic city perspective. Journal of Consumer Research 17: 454-462.

8. Thurau TH, Gwinner KP, Walsh G, Gremler DD (2004) Electronic Wordof-Mouth via Consumer-Opinion Platforms: What Motivates Consumers to Articulate Themselves on the Internet? Journal of Interactive Marketing 18 38-52.

9. Armstrong G, Kotler P (2011) Marketing; An Introduction (10 $10^{\text {th }}$ Ed.) N.J: Prentice Hall.

10. Bone PF (2000) Word-of-mouth effects on short-Term and long-term product judgments. Journal of Business Research 32: 213-223.

11. Dominici G, Guzzo R (2010) Customer Satisfaction in the Hotel Industry: A Case Study from Sicily. International Journal of Marketing Studies 2:3-12.

12. Fayyad UM, Shapior P, Smyth PG (1996) American Association for Artificial Intelligence, 37-54

13. Gelb BD, Sundaram S (2002) Adapting to word of mouse. Business Horizons 45: 21-25.

14. Thurau TH, Walsh G (2003) Electronic word-of-mouth: Motives for 
Citation: Yuan YH (2015) The Study on Relationship Verification of e-wom and Hotel Operation Performance by Data Mining Technique. J Glob Econ 3: 130. doi:10.4172/2375-4389.1000130

Page 4 of 4

consequences of reading customer articulations on the internet. International Journal of Electronic Commerce 8: 51-74.

15. Kumar V, Batista L, Maull R (2011) The Impact of Operations Performance on Customer Loyalty. Service Science 3: 158-171.
16. Wong TZ (2009) The development and challenge of data mining. Science Development Volume 442: 33-39.

17. Ye Q, Law R, Bin Gu (2009) The impact of online user reviews on hotel room sales. International Journal of Hospitality Management 28: 180-182. 